\title{
Habitat preferences and movement of adult yellowfishes in the Vaal River, South Africa
}

AUTHORS:

Gordon C. O'Brien ${ }^{1}$

Francois Jacobs ${ }^{1}$

Linda Cronje ${ }^{2}$

Victor Wepener ${ }^{1}$

Nicholas J. Smit ${ }^{1}$

\section{AFFILIATIONS:}

${ }^{1}$ Water Research Group, Unit for Environmental Sciences and Management, North-West University, Potchefstroom, South Africa

${ }^{2}$ Centre for Aquatic Research, Zoology Department, University of Johannesburg, Johannesburg, South Africa

\section{CORRESPONDENCE TO: Gordon O'Brien}

\section{EMAIL:}

gordon.obrien@nwu.ac.za

\section{POSTAL ADDRESS:}

Water Research Group, Unit for Environmental Sciences and Management, NorthWest University, Private Bag X6001, Potchefstroom 2520, South Africa

\section{DATES:}

Received: 05 Dec. 2012

Revised: 01 Mar. 2013

Accepted: 12 Mar. 2013

\section{KEYWORDS:}

Vaal River; yellowfish; habitat; movement; radio telemetry

\section{HOW TO CITE:}

O'Brien GC, Jacobs F, Cronje L, Wepener V, Smit NJ. Habitat preferences and movement of adult yellowfishes in the Vaal River, South Africa. S Afr J Sci. 2013;109(7/8), Art. \#0095, 8 pages. http://dx.doi.org/10.1590/ sajs.2013/20120095

(C) 2013. The Authors. Published under a Creative Commons Attribution Licence.
The yellowfishes of the Vaal River (Labeobarbus kimberleyensis and $L$. aeneus) are charismatic, socially and economically important fishes, but very little is known about their interspecies habitat preferences and movement. This study is the first behavioural study of yellowfish in the Vaal River using radio transmitters to characterise habitat preferences and movement patterns. A total of 22 adult $L$. kimberleyensis and 13 adult L. aeneus individuals were tracked for between 1 month and 1 year from 23 September 2006 to 16 May 2010. Radio telemetry revealed that yellowfish established routine daily behavioural patterns through which the habitat preferences and movement of the species could be established. Home ranges of the yellowfish ranged from $1 \mathrm{~km}$ to more than $12 \mathrm{~km}$ in the Vaal River depending on the species and habitat availability. Habitat preferences varied between species and included deep slow-flowing habitats with associated cover features particularly in winter for $L$. kimberleyensis and shallow fast-flowing habitats particularly for L. aeneus in spring, summer and autumn. Changes in flows, habitat availability and atmospheric pressure affected the movement of yellowfish. The biology and ecology of the yellowfish in the Vaal River is noticeably more complicated and dynamic than previously documented. We recommend that the behavioural ecology of these and other yellowfish populations in the Vaal River should continue to be characterised, and the use of the movement of yellowfish be developed as an indicator of ecosystem change.

\section{Introduction}

Knowledge of habitat use and associated requirements is needed to inform the management of fishes and the ecosystems in which they occur ${ }^{1,2}$ particularly for economically important species. ${ }^{2,3}$ Behavioural studies using movement as a variable have widely been used to evaluate the ecological consequences of changes in ecosystem conditions of both natural and anthropogenic origin. ${ }^{4-6}$

The Orange-Vaal largemouth yellowfish Labeobarbus kimberleyensis (Gilchrist and Thompson, 1913), and the Orange-Vaal smallmouth yellowfish $L$. aeneus (Burchell, 1822) are charismatic fishes that have both social and economic value in the Orange-Vaal River system in southern Africa. ${ }^{7,8}$ Both species are actively targeted by angling and subsistence fishing communities for food, and are used as indicator species in regional management and conservation plans. ${ }^{8-10}$ The Vaal River Labeobarbus spp. and other large African cyprinids are slow-growing, late-maturing and long-lived fishes, and these features increase their vulnerability to anthropogenic activities. ${ }^{11-13}$ Numerous water quality, quantity and habitat alteration impacts that negatively affect the biodiversity of the Vaal River have been identified. ${ }^{10,14}$ Notwithstanding the highly degraded habitat in the Vaal River, L. aeneus is abundant while L. kimberleyensis is rare. Labeobarbus aeneus is a 'Least Concern' species that is invasive in extra-limital situations throughout South Africa. ${ }^{15}$ In contrast, L. kimberleyensis is relatively rare and regarded as 'Near Threatened'.13,16,17 Although aspects of the biology and ecology of the Vaal River yellowfishes have been documented, their respective interspecies behavioural ecology, which is important to their management and conservation, is poorly known. ${ }^{14}$

Behavioural studies incorporating radio telemetry techniques have been used extensively to evaluate fish biology, ecology and ecotoxicology. ${ }^{4,6}$ In particular, radio telemetry techniques have been used to characterise basic biological parameters of fishes, such as movement and critical habitat requirements, using a small number of individuals. ${ }^{4,18-22}$ Radio telemetry studies have also been used to evaluate the ecological consequences of changes in ecosystem conditions such as rapid increases in flows and temperature changes..$^{4-6}$ Although these methods are well established internationally, they have only recently received attention in southern Africa. ${ }^{5,23-25}$

In this experiment we tested the hypothesis that the spatial area use, habitat preferences and movement patterns of the yellowfish in the Vaal River differ between species. The aim of this study was to monitor the locations of a sample of adult $L$. kimberleyensis and $L$. aeneus over an extended period of time in the Vaal River and characterise the habitat use and movement patterns of the individuals. In this paper, we present the findings of the first dedicated radio telemetry based behavioural study carried out on adult $L$. kimberleyensis $(n=22)$ and $L$. aeneus $(n=13)$ in the Vaal River.

\section{Study area}

The study was carried out in a reach of the middle Vaal River, southwest of Johannesburg (Figure 1). The study area is located within the Orange-Vaal River Yellowfish Conservation and Management Association (OVRYCMA) area. Site selection was based on local OVRYCMA member information, historical catch records for yellowfish, historical data ${ }^{5}$ and initial field surveys to ascertain the presence of sufficient adult yellowfish individuals for the study. The approximately 190-km reach of the Vaal River selected for the study extends from Parys to an area upstream of Bothaville (Figure 1). Within this reach, both L. kimberleyensis and L. aeneus are abundant, ${ }^{4}$ despite disturbances such as water abstraction for agriculture, industry and mine use, wastewater releases and the use of natural products. Habitat diversity was considered to be representative of the middle reach of the Vaal River and included a high diversity of both deep $(>3 \mathrm{~m})$ and shallow areas $(<1 \mathrm{~m})$ with slow- $(0 \mathrm{~m} / \mathrm{s})$ and fast-flowing $(1 \mathrm{~m} / \mathrm{s})$ biotope types. Although some gauging weirs and other barriers that may affect the movement of yellowfish exist in the study area, all of the yellowfish monitored in the study had access to relatively large reaches of the Vaal $\operatorname{River}(>35 \mathrm{~km})$. 


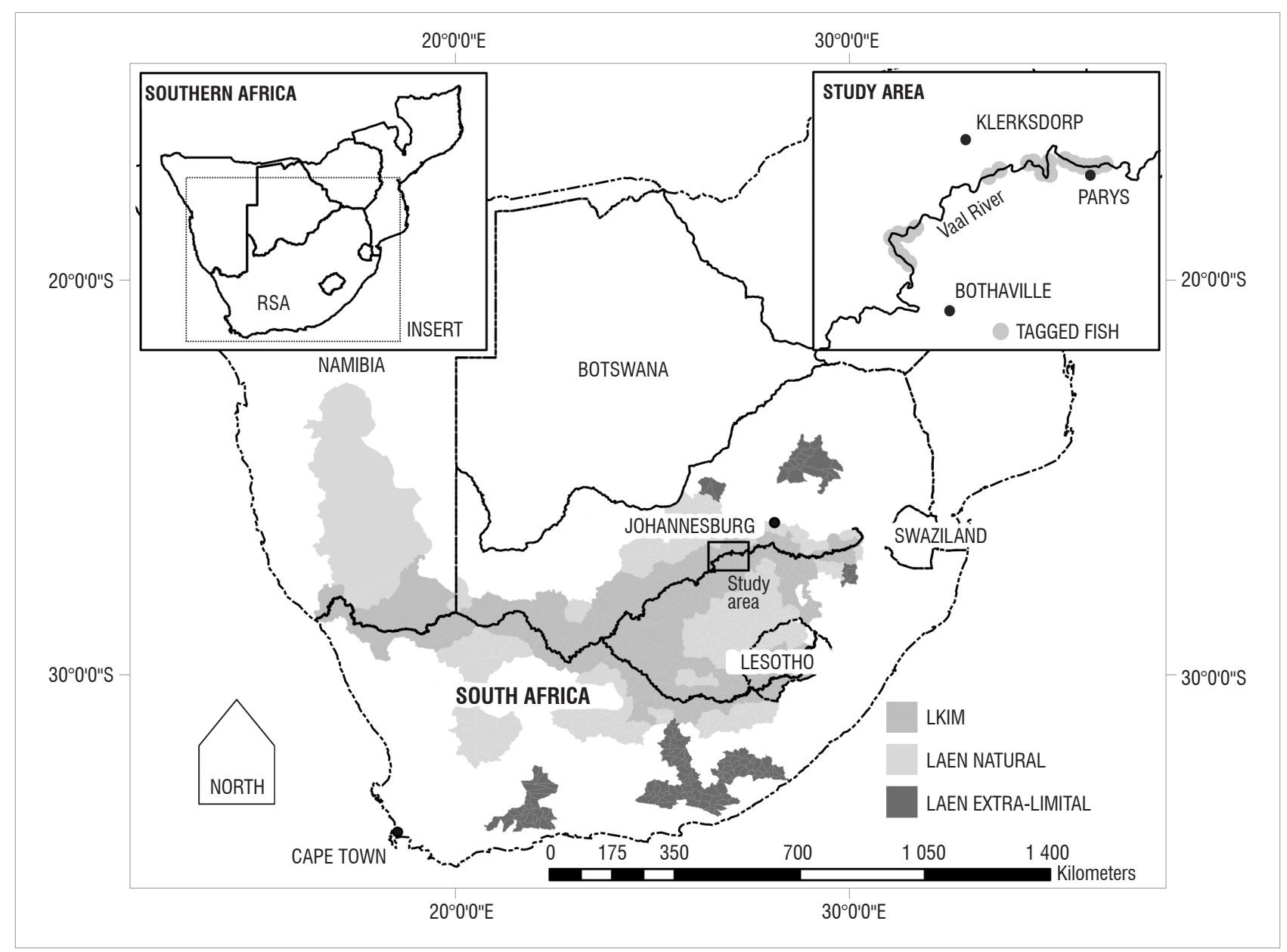

Figure 1: Map showing the distributions of Labeobarbus kimberleyensis (LKIM) and L. aeneus (LAEN) and the location of the study area on the Vaal River, southern Africa.

\section{Materials and methods}

\section{Tagging methods}

Adult L. kimberleyensis $(n=22)$ and $L$. aeneus $(n=13)$ were monitored for up to 1 year. Radio transmitters (Advanced Telemetry Systems Inc. (ATS), Isanti, MN, USA) were attached and manually tracked from 7 July 2007 to 24 August 2010 (see Supplementary table 1 online for transmitter data). In this study, ATS model 2030 and 2120 external mount transmitters, ATS R2100 and R4500 receivers and Yagi 4-element antennae were used for tracking. Monitoring surveys were carried out on foot along the bank of the Vaal River, in small inflatable boats and by air in a fixed wing aircraft, using standard approaches. ${ }^{25}$ Adult yellowfish weighing 1050-6200 $\mathrm{g}$ were selected for the study to ensure that the transmitters did not exceed $2 \%$ of their mass, ${ }^{26}$ as the effects of the tags were not evaluated directly. ${ }^{13,27,28}$

Yellowfish were captured using various netting and angling techniques as well as a boat-mounted electrofisher (1 kV). The netting techniques included the use of monitored gill nets deployed in the evening and early morning, large fyke net traps and large seine nets. After capture, yellowfish were partially anaesthetised with either 2-phenoxy-ethanol $(0.4 \mathrm{~mL} / \mathrm{L})$ or clove oil $(0.1 \mathrm{~mL} / \mathrm{L})$, until signs of partial anaesthesia were evident. ${ }^{29}$ Transmitters were surgically attached dorsolaterally through the musculature at the base of the dorsal fin using stainless steel wire. Tagging procedures were based on the external attachment methods that have successfully been used in regional biotelemetry studies with ATS transmitters. ${ }^{25}$ Although the tagged yellowfish were monitored immediately to evaluate survival and recovery from the tagging procedures, we used only behavioural data collected more than 2 weeks after release. ${ }^{30,31}$

\section{Spatial behaviour and habitat preferences}

Random and dedicated continuous 24-h surveys were carried out. During the monitoring surveys, the positions ( $\pm 1 \mathrm{~m}$ accuracy) of the tagged yellowfish were documented using a detailed georeferenced map of the site or a georeferenced spatial imaging system on a handheld GeoExplorer ${ }^{\circledR} 3000$ Trimble (Trimble Navigation Ltd., Sunnyvale, CA, USA). The longitudinal reaches of the river repeatedly traversed by each tagged yellowfish during the study (for a period of up to 1 year) were used to establish home ranges. ${ }^{32}$ Preferred or high-use areas included river reaches that were considerably smaller than the home range of the individual which were frequented ( $>25 \%$ of the location data) during the study. After locating the tagged yellowfish, the movement or total roaming distance of a tagged yellowfish during four consecutive 10-min intervals was documented. Displacement categories were established to describe inactive $(0.1 \mathrm{~m} / \mathrm{min})$, slow-moving $(1 \mathrm{~m} / \mathrm{min})$, fast-moving $(5 \mathrm{~m} / \mathrm{min})$ or very fast-moving $(10 \mathrm{~m} / \mathrm{min})$ yellowfish in the study. Additional behavioural data including the habitat associated with the positions of individuals, activity (such as feeding, holding or migrating) and state of various environmental parameters were documented using scoring data sheets and a diary of anecdotal observations.

Habitat variables considered included fish cover features, water column depth, water clarity, substrate types and flow-dependent habitat classes $^{33}$ (Table 1). To facilitate the evaluation of physical habitat biotope use in relation to availability, three-dimensional digital terrain models of frequently used areas of the study area were generated. Models were generated using ARC GIS ${ }^{\circledR}$ (ESRI, Redlands, CA, USA) from data that was collected from a Hummingbird ${ }^{\circledR} 789 \mathrm{CI}$ (Hummingbird Ltd., Eufaula, AL, USA) side scan fish finder. The influence of changing flow (discharge), temperatures and atmospheric pressure on the movement 
of the yellowfish were evaluated retrospectively. $\mathrm{HOBO}^{\circledR}$ pendant temperature loggers (Onset Computer Corporation, Bourne, MA, USA), type UA-001-08 were deployed into the study area to log temperatures. Flow data were obtained from the Department of Water Affairs gauging stations - C2H007Q01 at Pilgrims estate in Orkney and C2H018Q01 at Schoemansdrift - located within the study area. Atmospheric pressure was measured using a calibrated SILVA ADC summit weather station/ anemometer (Stockholm, Sweden) that was stationed within the upstream and downstream boundaries of the reach considered.

\section{Data analysis}

The location and movement data were analysed for spatial and temporal trends using ARC GIS ${ }^{\circledR}$. This analysis allowed for the assessment of the use of spatial area by individuals, the existence of high-use, preferred areas and some relationships between the locations of the tagged fish and environmental variables. ${ }^{32}$ The habitat selectivity of fish monitored in the study was evaluated using Ivlev's electivity index $\left(E_{i}\right) \cdot 34,35$ This test allows for the assessment of the selection of habitat by association in relation to the availability of habitat types (Table 1), generated in the representative digital terrain models in the study as follows:

$E_{i}=\frac{r_{i}-n_{i}}{r_{i}+n_{i}}$

Equation 1

where $r_{i}$ is the percentage of habitat $i$ used by the fish and $n_{i}$ is the percentage of habitat $i$ available in the environment. The electivity index varies from -1 to +1 where values between 0 and +1 indicate habitat preference and 0 to -1 indicate avoidance. ${ }^{34}$

The influence of seasonality and discharge, substrate, biotope and fish cover feature types, water temperatures and atmospheric pressure differences on movement (measured as maximum displacement per minute, MDPM) were evaluated using a mixed-model analysis of variance ${ }^{31}$ with a random coefficients model..$^{36}$ The combined species data were normally distributed and therefore the Akaike's Information Criteria model selection ${ }^{37}$ was used as a multiple comparisons test for significance. These analyses were conducted using SAS version 9.3 (SAS Institute, Cary, NC). The potential influences of daily spring/summer discharge increases (from $10 \mathrm{~m}^{3} / \mathrm{s}$ to $20 \mathrm{~m}^{3} / \mathrm{s}$ ) and annual flood flow increases (from $40 \mathrm{~m}^{3} / \mathrm{s}$ to $60 \mathrm{~m}^{3} / \mathrm{s}$ ) on the movement of yellowfish were considered. Daily increases in atmospheric pressure between $5 \mathrm{mb}$ and $10 \mathrm{mb}$ were included. The interspecies effect of seasonality, discharge, substrate, biotope and fish cover feature types on the movement of the yellowfishes were analysed following the approach adopted by O'Brien et al. ${ }^{25}$ using SPSS 20 (SPSS, Chicago, IL, USA). Mann-Whitney U-tests were employed to test if the coefficients of variation in the MDPM were significantly different at the $p=0.05$ level. Thereafter, the Kruskal-Wallis test was employed to evaluate the statistical relationships between MDPM and flows and pressures.

\section{Results}

The yellowfish were located on 660 occasions resulting in 2640 locality fixes during random monitoring and 78 24-h surveys (see Supplementary table 1 online). As shown in Supplementary table 1, 7 of the 22 L. kimberleyensis and 4 of the $13 \mathrm{~L}$. aeneus individuals contributed to $>70 \%$ of each species' data. L. kimberleyensis were located every 13.6 days ( \pm 67.2 days) and $L$. aeneus every 6.1 days ( \pm 11.2 days).

\section{Labeobarbus kimberleyensis: Spatial behaviour}

\section{and habitat preferences}

The adult $L$. kimberleyensis individuals that had an average mass of $3500 \mathrm{~g}( \pm 1212 \mathrm{~g})$ were tracked on 2 to 42 occasions resulting in 1064 fixes (4 every 10 min per observation). After release, the L. kimberleyensis remained largely inactive in close proximity $(<150 \mathrm{~m})$ to the release site for 2-3 days, particularly in winter. During these initial recovery periods, suitable deep $(>1.5 \mathrm{~m})$ slow-flowing $(<0.8 \mathrm{~m} / \mathrm{s})$ habitats occupied were frequently $(>75 \%)$ associated with undercut banks, or some form of cover feature such as overhanging vegetation, submerged or exposed rocky ridges or aquatic vegetation. After the initial recovery, i.e. from day 3, the L. kimberleyensis individuals moved away (500 m to $12 \mathrm{~km}$ ) from the tagging area. Within 2 weeks, all $L$. kimberleyensis appeared to have recovered from the tagging process and established routine, repeatable behavioural patterns within large (up to $12 \mathrm{~km}$ ) defined home ranges $^{32}$ (Figure 2). The majority of the $L$. kimberleyensis used between $4 \mathrm{~km}$ and $7 \mathrm{~km}$, with the smallest home range documented to be $1.5 \mathrm{~km}$. Some of the $L$. kimberleyensis $(n=7)$ tracked for extended periods

Table 1: Habitat biotope types recorded in the study for yellowfish in the Vaal River

\begin{tabular}{|c|c|c|c|c|}
\hline \multirow[t]{2}{*}{ Habitat biotopes } & $\begin{array}{c}\text { Habitat availability } \\
(\%)\end{array}$ & \multirow[t]{2}{*}{$\begin{array}{l}\text { Approximate velocity } \\
\qquad(\mathrm{m} / \mathrm{s})\end{array}$} & \multirow[t]{2}{*}{ Surface flow types } & \multirow[t]{2}{*}{ Substrate types } \\
\hline & Site 1 & & & \\
\hline \multicolumn{5}{|l|}{ Pool habitats } \\
\hline Backwater pool & \multirow{3}{*}{56} & 0 & \multirow{2}{*}{ Barely perceptible flow } & \multirow{3}{*}{ Silt, sand and gravel } \\
\hline Slackwater pool & & $0-0.05$ & & \\
\hline True pool & & 0.075 & Smooth and turbulent & \\
\hline \multicolumn{5}{|l|}{ Glides } \\
\hline Slow glides & \multirow{2}{*}{12} & 0.075 & Smooth and turbulent & Silt, sand and gravel \\
\hline Fast glides & & 0.1 & Smooth and turbulent & Gravel, cobble and boulders \\
\hline Run & 11 & 0.2 & & \\
\hline \multicolumn{5}{|l|}{ Riffle habitats } \\
\hline Slow riffle & \multirow{2}{*}{9} & 0.3 & \multirow{2}{*}{ Riffle surface } & \multirow{2}{*}{ Cobble, boulder and bedrock } \\
\hline Fast riffle & & 0.4 & & \\
\hline \multicolumn{5}{|l|}{ Rapid habitats } \\
\hline Rapid - true & \multirow{2}{*}{10} & 0.5 & \multirow{2}{*}{ Undular or breaking standing waves } & \multirow{2}{*}{ Boulder and bedrock } \\
\hline Rapid - fast & & 0.75 & & \\
\hline Cascades & 1 & 1 & Chaotic flow & Bedrock \\
\hline Chutes & 1 & 3 & Free fall & Bedrock \\
\hline
\end{tabular}


(>6 months) demonstrated high-use areas or focus areas of the Vaal River, of approximately $2 \mathrm{~km}$ (maximum $4 \mathrm{~km}$ ).

The $L$. kimberleyensis tracked in the study made use of a wide range of habitat types that changed during seasons (Figure 3a). Slow-flowing pool and glide habitats were frequented more often than fast-flowing run riffle and rapid habitats. As the seasons progressed from autumn to summer, the frequency of use of pool habitats generally decreased from $54 \%$ (autumn) and 57\% (winter) to 32\% (spring) and 13\% (summer). Habitats that were more frequently used during spring and summer included run and riffle habitats, with use increasing from $7 \%$ (winter) and $8 \%$ (autumn) to approximately $17 \%$ (summer and spring) and from $5 \%$ (autumn) and $8 \%$ (winter) to $19 \%$ (spring) and $42 \%$ (summer), respectively. The frequency of use of glides by L. kimberleyensis decreased from $32 \%$ (autumn) to 25\% (summer). Ivlev's electivity scores indicate that L. kimberleyensis in the Vaal River have a preference for glide habitats throughout the year (Figure 3b). Run and riffle habitats were avoided by L. kimberleyensis during autumn and winter and selected during spring and summer. Autumn and winter trends in decreasing preference for habitat types with increasing velocities from glides to rapids were evident. In particular, fast-flowing rapid habitats were avoided by this species throughout the year. Although the tracking results indicate that pools were used frequently, the $\mathrm{E}_{\mathrm{i}}$ scores indicate that there was slight avoidance of this habitat type, particularly during spring and summer.

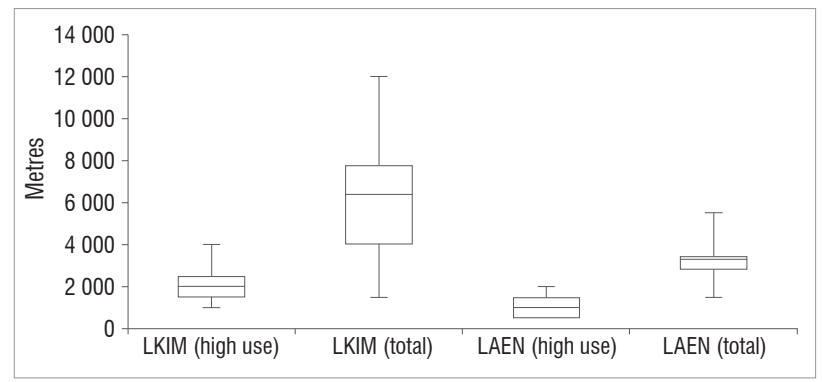

Figure 2: Graphical representation of the kernel size (kernel) and maximum displacement or area use of adult Labeobarbus kimberleyensis (LKIM) and L. aeneus (LAEN) in the Vaal River. Box-and-whisker plots include the 25th and 75th percentiles (boxes) and 5th and 95th percentiles (whiskers) of area use.

\section{Labeobarbus aeneus: Spatial behaviour and habitat preferences}

We obtained 804 fixes on adult $L$. aeneus individuals of an average mass of $2707 \mathrm{~g}( \pm 897 \mathrm{~g})$. Similarly to L. kimberleyensis, after release the $L$. aeneus remained relatively inactive in suitable deep refuge areas for 2-3 days. After recovery, $L$. aeneus generally remained within the vicinity $(<500 \mathrm{~m})$. Within 2 weeks, all $L$. aeneus also appeared to have recovered and established routine daily behavioural patterns within moderate home ranges of up to $5.5 \mathrm{~km}$. The majority of the $L$. aeneus $(n=12)$ exhibited high-use areas of $800 \mathrm{~m}$ (maximum $2 \mathrm{~km})$; some individuals (LAEN1, LAEN7 and LAEN13) tracked over extended periods (124-411 days) remained exclusively within these focus areas.

Habitat types frequented by $L$. aeneus were dominated by glides and pools during winter, glides alone in spring and runs in summer (Figure 3c). A shifting trend in preference for habitats with increasing flows from pools to riffles was observed from autumn to summer. Rapids were infrequently used in spring ( $9 \%$ of the time) and summer ( $11 \%$ of the time). Rapid initial decreases in use frequency of run (31\% to $10 \%)$ and riffle (22\% to $6 \%)$ habitats from autumn to winter were observed. This decrease was followed by gradual increases to similar spring levels during summer. The $E_{\text {s }}$ scores obtained for $L$. aeneus indicate that this yellowfish prefers moderate to fast-flowing habitat types throughout the year and avoids pools (Figure $3 \mathrm{~d}$ ). During autumn and winter, the very fast-flowing rapid habitats and fast-flowing riffle habitats (in winter only) were also avoided by $L$. aeneus for run and glide habitats.

\section{Labeobarbus kimberleyensis: Movement}

The L. kimberleyensis monitored in the study generally established routine daily behavioural patterns that varied between seasons (Table 2). These patterns were disrupted when sudden changes in flow and/or water quality occurred. Responses usually involved the occupation of suitable individual specific refuge areas. Each individual demonstrated affinity for fewer than five refuge areas. On occasion, if the disrupted conditions persisted, the individual would vacate its established home range. One such occasion was the extreme case of the flood in January 2010. Although one L. kimberleyensis did not vacate its home range during this event, three others did. Findings showed that although the movement of both yellowfish species increased significantly during spring $(p<0.05)$, no significant seasonal changes in the movement of $L$. kimberleyensis were observed. Significant $(p<0.05)$ decreases

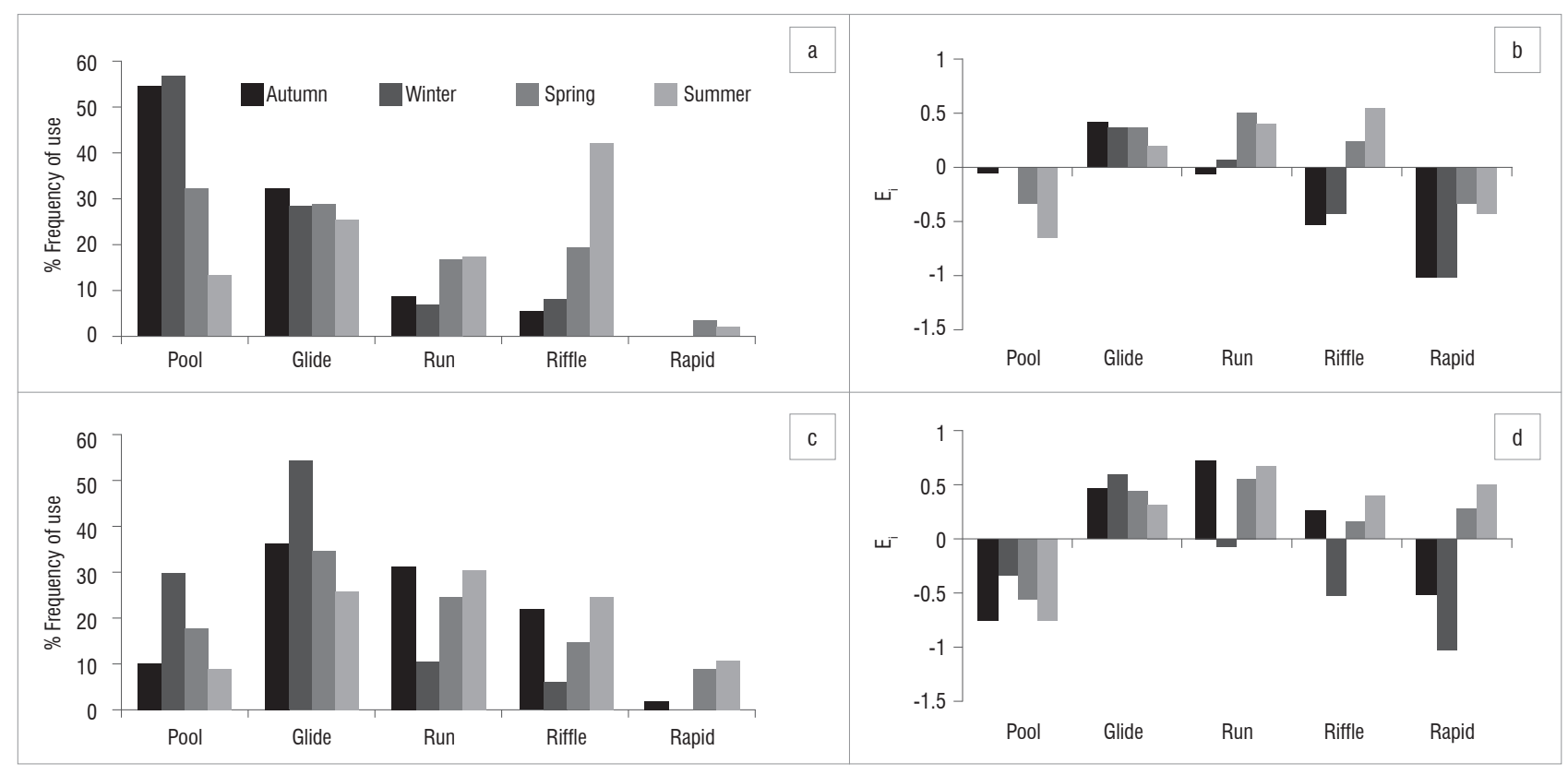

Figure 3: Percentage frequency of habitat biotope use by (a) Labeobarbus kimberleyensis and (b) L. aeneus in autumn, winter, spring and summer. Comparative Ivlev's electivity index $\left(E_{j}\right)$ scores for habitat use of (c) L. kimberleyensis and (d) L. aeneus in autumn, winter, spring and summer. 
in movement were, however, correlated with rapid daily increases in discharge. During 2009 and 2012, as many as seven freshet events that resulted in changes in movement of the yellowfish were documented (Figure 4). Rapid increases in atmospheric pressure in winter were positively correlated with a decrease in movement of $L$. kimberleyensis $(p<0.073)$. During these events, the L. kimberleyensis individuals would abandon daily behavioural patterns to take refuge in deep habitats for the duration of the weather event, which could last for up to 10 days after the onset of the pressure change (Figure 5). During 2009, three weather events affected the movement of both yellowfishes monitored in the study: 29 July to 01 August (Figure 5, \#1), 12 August to 14 August (Figure 5, \#2) and 18 August to 20 August (Figure 5, \#3).

Table 2: Statistical analysis of the relationships between changes in movement (measured as maximum displacement per minute) of yellowfish in the Vaal River and selected environmental variables using analysis of variance techniques incorporating Akaike's Information Criteria and Mann-Whitney U-tests

\begin{tabular}{|l|c|c|c}
\hline \multirow{2}{*}{ Environmental variable } & \multicolumn{2}{|c|}{ Mann-Whitney U-test } & \multirow{2}{*}{$\begin{array}{c}\text { ANOVA } \\
\text { (LKIM and LAEN) }\end{array}$} \\
\cline { 2 - 3 } & LKIM & LAEN & \\
\hline \hline Season & \multicolumn{2}{|c|}{$0.047^{\star \star \#}$} & 0.055 \\
\hline Autumn & 0.877 & 0.315 & 0.781 \\
\hline Spring & 0.329 & 0.421 & $0.02^{\star}$ \\
\hline Summer & 0.768 & 0.078 & 0.343 \\
\hline Winter & 0.578 & 0.495 & 1.000 \\
\hline Discharge & $0.004^{\star}$ & $0.042^{*}$ & $0.002^{*}$ \\
\hline Biotopes & \multicolumn{2}{|c|}{$0.0001^{\star *}$} & $0.001^{*}$ \\
\hline Backwater & 0.210 & 0.316 & 0.577 \\
\hline Pool & 0.014 & 0.370 & $0.001^{*}$ \\
\hline Glide & 0.880 & 0.570 & $0.001^{*}$ \\
\hline Riffle & 0.161 & $0.021^{*}$ & $0.022^{*}$ \\
\hline Run & 0.950 & 0.775 & 1.000 \\
\hline Atmospheric pressure (mb) & \multicolumn{2}{|c|}{$0.78^{\#}$} & $0.001^{*}$ \\
\hline Summer rapid increases & 0.470 & 0.121 & 0.700 \\
\hline Summer rapid decreases & 0.827 & 0.700 & 0.676 \\
\hline Winter rapid increases & 0.073 & 0.090 & 0.065 \\
\hline Winter rapid decreases & 0.095 & 0.225 & 0.090 \\
\hline
\end{tabular}

LKIM, Labeobarbus kimberleyensis; LAEN, Labeobarbus aeneus

*denotes significant relationships

\#denotes interspecies comparisons

\section{Labeobarbus aeneus: Movement}

Although $L$. aeneus adopted routine daily behavioural patterns similar to $L$. kimberleyensis, significant seasonal interspecies differences were observed $(p<0.05)$. In particular, there was a strong correlation $(p=0.078)$ between the increase in movement of $L$. aeneus and the summer period. Rapid daily increases in discharge resulted in a significant $(p<0.05)$ decrease in the movement of $L$. aeneus. The interspecies use of biotopes by $L$. aeneus and $L$. kimberleyensis differed significantly $(p<0.05)$. Movement of $L$. aeneus increased significantly when the individuals occupied riffle habitat types $(p<0.05)$. Although a strong correlation $(p<0.05)$ existed between the decrease in movement of $L$. aeneus and rapid daily increases in atmospheric pressure during winter, no significant relationships were observed. The use of refuge areas by $L$. aeneus individuals were less obvious than that for L. kimberleyensis and often required a major stimulus such as rapid increases in flows during floods and changes in pressure events. Only a few individuals vacated home ranges during the study.

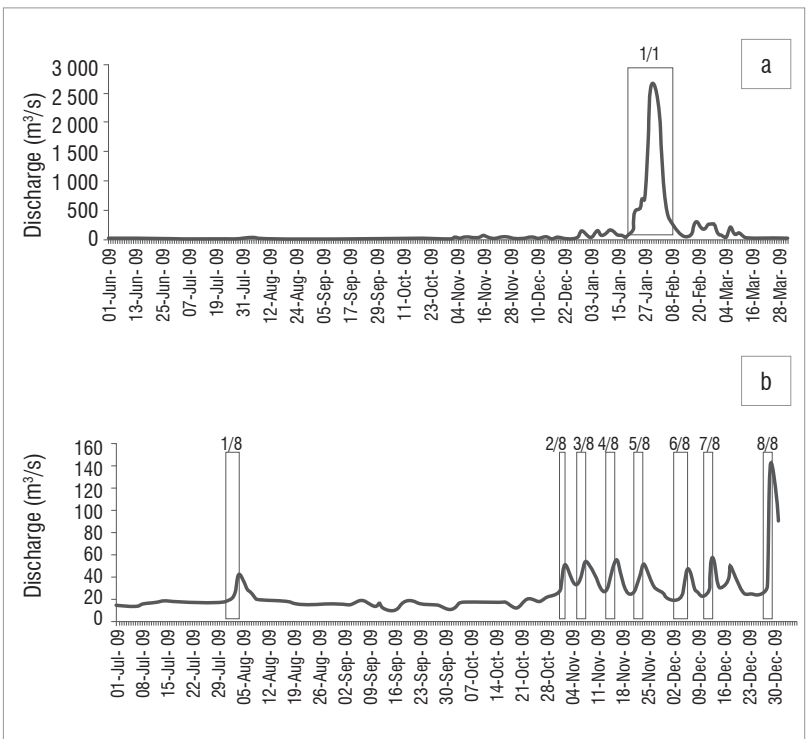

Figure 4: Graphical representation of flow from the Vaal River at Site 2 measured as discharge $\left(\mathrm{m}^{3} / \mathrm{s}\right)$, obtained from the Department of Water Affairs gauging weir no $\mathrm{C} 2 \mathrm{H} 018$ from (a) 01 June 2009 to 31 March 2010 and (b) 01 July 2009 to 31 December 2009. The flood event $(4 a, 1 / 1)$ and freshet events $(4 b, 1 / 8-8 / 8)$ considered in the study are indicated.

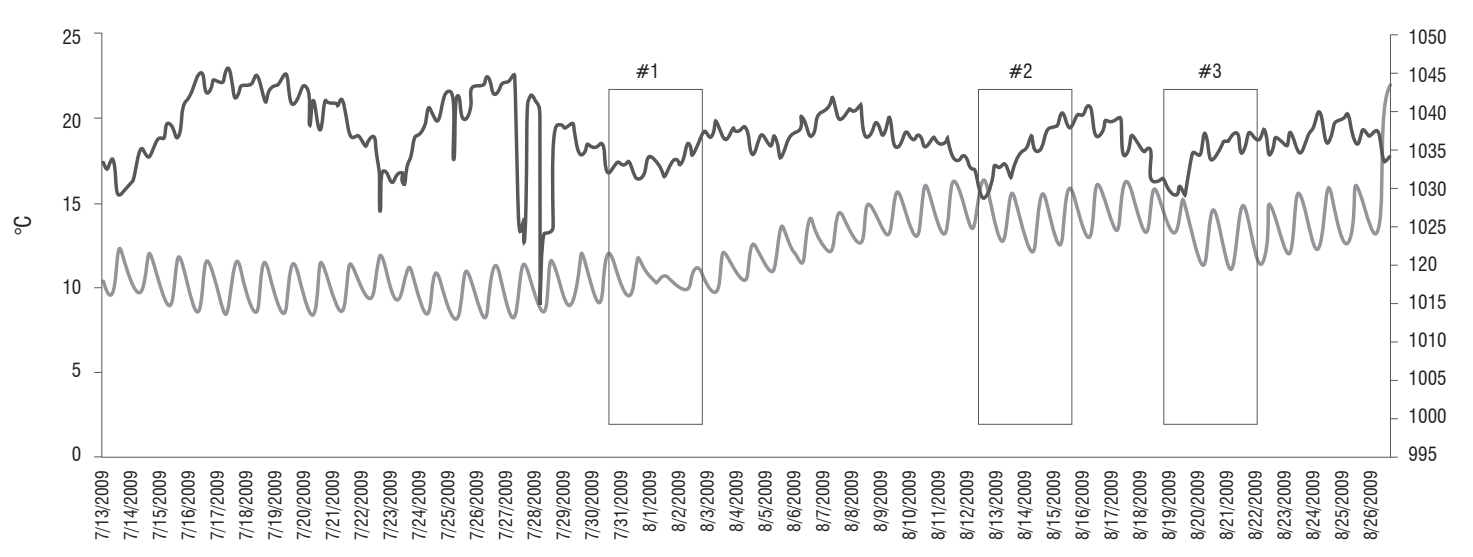

Figure 5: Graphical representation of atmospheric temperature (dark grey line) and water temperature (light grey line) $\left({ }^{\circ} \mathrm{C}\right.$ ) and atmospheric pressure (black line) (mb) at Site 2 from 13 July 2009 to 26 August 2009. Three weather events referred to in the text are indicated: 29 July to 01 August (\#1), 12 August to 14 August (\#2) and 18 August to 20 August (\#3). 
The movements of both species varied seasonally $(p=0.055)$, with a significant increase in the movement of both species in spring $(p<0.05)$. Similarly to the interspecies considerations, in combination, yellowfish movement changed significantly when discharge increased rapidly $(p<0.05)$ and when atmospheric pressure increased rapidly $(p<0.05)$ with rapid increases $(p=0.065)$ and decreases $(p=0.09)$ in winter being particularly important. Interestingly, in combination the movement of yellowfish was found to change significantly in relation to the use of pools and glide habitats $(p<0.05)$, which were preferred in winter, and riffle habitats $(p<0.05)$, which were preferred in summer.

\section{Discussion}

A wide range of behavioural ecology aspects of many adult cyprinids, including habitat use and selection, movement and the response to changing environmental variables, has been evaluated using radio telemetry techniques..$^{38-40}$ The outcomes of this study are the first account of the behavioural ecology of any yellowfish (Labeobarbus spp.). Cyprinids have been observed to have a high fidelity for sites ranging from a few hundred metres to many kilometres ${ }^{40-42}$ but have also been observed to be highly mobile and capable of moving over hundreds of kilometres at a high rate (up to $8 \mathrm{~km} /$ day) ${ }^{42}$ The yellowfish considered in this study showed high fidelity for sites ranging from less than $1 \mathrm{~km}$ for $L$. aeneus to $12 \mathrm{~km}$ for $L$. kimberleyensis. The distribution of some cyprinids is considered to be driven by habitat availability, system morphometry and spawning and seasonal factors. ${ }^{40}$ Although the reach of the Vaal River used by Labeobarbus spp. may similarly be influenced by habitat requirements and availability, the differences in home range size may be associated with the roaming predatory nature of $L$. kimberleyensis and omnivorous foraging feeding biology of $L$. aeneus. ${ }^{14,28,43,44}$ Labeobarbus kimberleyensis establish home ranges that are, on average, twice the length of those established by $L$. aeneus. Focus or high-use areas were also established by both species, but were, again, greater for L. kimberleyensis $(2 \mathrm{~km})$ than for $L$. aeneus $(800 \mathrm{~m})$. The Vaal River yellowfishes have species-specific preferences for habitat types that differ among seasons, similarly to other cyprinids, ${ }^{40}$ indicating that considerable differences in the biology of the species exist. L. kimberleyensis prefers deep (>1 m), slow-flowing pool and glide habitats, particularly during autumn and winter. During these periods, adult predatory yellowfish have access to known prey items including small fishes and large invertebrates. ${ }^{14}$ The shift towards running water by L. kimberleyensis in summer suggests that the preferred slowflowing habitat types may either become unsuitable during high-flow periods, as a result of changes in temperatures or turbidity for example, or that the species takes advantage of a resource that is only available during these periods. ${ }^{45}$ Changes in ecosystem variable states such as increases in turbidity have been shown to affect the feeding and breeding behaviour of cyprinids. ${ }^{38,45} \mathrm{~L}$. aeneus appears to be a facultative rheophilic, omnivorous yellowfish that forages predominantly in shallow $(<1 \mathrm{~m})$ fast-flowing habitats. ${ }^{43,44,46,47}$ The gut contents of a $L$. aeneus population from the Great Fish River were found to be dominated by Simulidae larvae which can easily be obtained by grazing in shallow fastflowing habitats. ${ }^{48}$ These findings indicate that $L$. aeneus in the Vaal River frequent a wide range of habitats, including shallow fast-flowing riffles and runs as well as deep slow-flowing pool habitats. Only in autumn and winter, when the flow, temperature and/or atmospheric conditions became variable or unstable, did $L$. aeneus show an affinity for deep water habitats. The reduction in use of pool habitats in spring and summer may have occurred as a result of possible decreases in oxygen in these habitats at higher temperatures during spring and summer.

Changes in environment have been shown to affect the behaviour of cyprinids ${ }^{38}$ In this study the movement of both yellowfishes was shown to be influenced by rapid increases in flow and atmospheric pressure. Responses involved the coordinated movement of individuals into suitable refuge areas or the vacation of high-use and/or home range areas. Refuge areas consisted of relatively deep areas that were generally sheltered by steep banks, or submerged or emerged rocky ridges for example where water flow and sudden surface-associated temperature changes could be avoided. Freshet and annual flood events caused $L$. kimberleyensis individuals initially to vacate their existing high-use and/or home range areas. When flow conditions stabilised, the L. kimberleyensis individuals generally did not return to established home ranges but established new home ranges, depending on what seemed to be the availability of resources.

Yellowfish in the Vaal River have historically been known to undertake coordinated upstream spawning migrations during spring or summer. ${ }^{49}$ In this study, no coordinated upstream migrations were observed. In contrast, when changes in various ecosystem conditions caused individuals with established kernel areas to vacate these areas, both upstream and downstream migrations were observed. Although coordinated upstream spawning migrations may no longer occur, or may occur only during conditions that were not experienced during this study, the frequent uncoordinated upstream and downstream migrations of $L$. kimberleyensis individuals, in particular, following, for example, rapid increases in flow, may still allow mixing of individuals from different populations. Although the reproductive strategies of $L$. aeneus have been well documented, only limited information is available for L. kimberleyensis, specifically within riverine habitats. ${ }^{13,14,27,28,50,51}$ In this study, only one possible spawning event, on 26 October 2007, was documented. This event involved abnormal vigorous interspecies shoaling behaviour of a group $(n>5)$ of $L$. kimberleyensis, one of which was a tagged individual (LKIM8). The behaviour occurred in a confined $\left(<16 \mathrm{~m}^{2}\right)$ reach of the study area at the base of an island in a relatively deep $( \pm 1.6 \mathrm{~m})$ glide that was dominated by sand and gravel. L. kimberleyensis are known to spawn 4 to 6 weeks later than the more cold-tolerant $L$. aeneus - a fact which is supported by our findings. 13,14,27,28 Numerous spawning events of tagged and other L. aeneus were, however, documented in the main stream of the Vaal River and in some smaller side channels. Findings confirm observations elsewhere ${ }^{28,52}$ that $L$. aeneus spawning events are initiated when water temperatures in the Vaal River reach $18.5^{\circ} \mathrm{C}$, in late September to early October. In 2009, Weyl et al. ${ }^{15}$ showed that the spawning success of L. aeneus was dependent on access to riverine habitats or suitable lentic habitats where flow cues were available. In this study, spawning events of $L$. aeneus were coordinated with increases in the frequency of freshet flows during spring when rapid increases in temperature were observed. These events occurred in riffle and rapid habitats where gravel, cobble and boulder substrates dominate. Riverine $L$. aeneus populations have been observed to use similar gravel beds for spawning and may use other similar habitats (e.g. rocky shores in lentic ecosystems) but actual data is unavailable. ${ }^{28}$ These findings support the known spawning requirements of $L$. aeneus, namely that in the Vaal River the population requires water temperatures above $18.5^{\circ} \mathrm{C}$ and stream flow cues with access to suitable gravel or cobble beds. ${ }^{15,28}$

The Vaal River is known to be affected by a range of water quantity, quality and habitat altering impacts. ${ }^{53-57}$ If these impacts persist, changes in the biology and ecology of the yellowfishes may result and ultimately affect the survivability of these species. The habitat requirements and the behavioural response information of the yellowfishes to changes in flows and weather events can be used to manage yellowfish and the Vaal River in which they occur. To further characterise the biology and ecology of the Vaal River yellowfishes for the management and conservation of these fishes and the Vaal River, we recommend that the behavioural ecology of these and other populations continue to be characterised and used as an indicator of ecosystem change.

\section{Acknowledgements}

We acknowledge the Water Research Commission of South Africa, the Endangered Wildlife Trust and FlyCastaway for funding the study, and the Hoffman family from Wag ' $n$ Bietjie, Kobus Fourie from the Elgro River lodge and Rocky Ridge in Parys for logistical support. We also acknowledge the contributions made by Pierre De Villiers, the Yellowfish Working Group, the Orange Vaal River Yellowfish Conservation and Management Organisation, other students and researchers and various anglers, particularly Garth Wellman, Horst Filter and Maurice Robertson, who assisted with the capture of yellowfish for the study. Finally, we acknowledge the efforts of Dr Suria Ellis of the Statistical Consultation 
Service of the North-West University who carried out all mixed-model statistical analyses using SAS statistical software.

\section{Authors' contributions}

G.C.O'B. was the project leader and senior specialist on the study and was responsible for the project plan and experimental design, data analyses and writing the manuscript. F.J. and L.C. collected the data and contributed to the data analyses. V.W. and N.J.S. contributed to the data analyses and edited the manuscript.

\section{References}

1. Hermasen H, Krog C. A review of brown trout (Salmo trutta) spawning beds, indicating methods for reestablishment in Danish lowland rivers. In: Alabaster JS, editor. Habitat modification and freshwater fisheries: Proceedings of a Symposium of the European Inland Fisheries Advisory Commission. London/ Rome: Butterworths/FA0; 1985.

2. Hurber M, Krichhofer A. Radio telemetry as a tool to study habitat use of nase (Chondrostoma nasus L.) in medium-sized rivers. Hydrobiologia. 1998;371/372:309-319. http://dx.doi.org/10.1023/A:1017005523302

3. Lucas MC, Frear PA. Effects of a flow-gauging weir on the migratory behaviour of adult barbell, a riverine cyprinid. J Fish Biol. 1997;50:382-396. http://dx.doi.org/10.1111/j.1095-8649.1997.tb01366.x

4. Cooke SJ, Hinch SG, Wikelski M, Andrews RD, Kuchel LJ, Wolcott TG, et al. Biotelemetry: A mechanistic approach to ecology. Trends Ecol Evol. 2004;19:334-343. http://dx.doi.org/10.1016/j.tree.2004.04.003

5. Økland F, Thorstad EB, Hay CJ, Næsje TF, Chanda B. Patterns of movement and habitat use by tigerfish (Hydrocynus vittatus) in the Upper Zambezi River (Namibia). Ecol Freshw Fish. 2005;14:79-86. http://dx.doi.org/10.1111/ j.1600-0633.2004.00080.x

6. Gerhardt A. Aquatic behavioral ecotoxicology - Prospects and limitations. Hum Ecol Risk Assess. 2007;13:481-491. http://dx.doi.org/10.1080/ 10807030701340839

7. De Villiers P, Ellender B. Status of the Orange-Vaal largemouth yellowfish, Labeobarbus kimberleyensis (Gilchrist \& Thompson, 1913). In: Impson ND, Bills IR, Wolhuter L, editors. Technical report on the state of yellowfishes in South Africa. Technical report no. KV 212/08. Pretoria: Water Research Commission; 2008. p. 92-102.

8. Brand M, Maina J, Mander M, O'Brien GC. Characterisation of the social and economic value of the use and associated conservation of the yellowfishes in the Vaal River. WRC report no. KV 226/09. Pretoria: Water Research Commission; 2009

9. Skelton P. A complete guide to the freshwater fishes of southern Africa. Cape Town: Struik Publishers; 2001. p. 167-168.

10. Wepener V, Van Dyk C, Bervoets L, O'Brien GC, Covacic A, Cloete Y. An assessment of the influence of multiple stressors on the Vaal River, South Africa. Phys Chem Earth. 2011;36(14-15):949-962.

11. Skelton PH, Tweddle D, Jackson P. Cyprinids of Africa. In: Winfield IJ, Nelson JS, editors. Cyprinid fishes, systematics, biology and exploitation. London: Chapman \& Hall; 1991. p. 211-239. http://dx.doi.org/10.1007/978-94-0113092-9_7

12. Granek EF, Madin EMP, Brown MA, Figueira W, Cameron DS, Hogan Z, et al. Engaging recreational fishers in management and conservation: Global case studies. Cons Biol. 2008;22(5):1125-1134. http://dx.doi.org/10.1111/ j.1523-1739.2008.00977.x

13. Ellender BR, Weyl OLF, Winker $\mathrm{H}$. Age and growth and maturity of southern Africa's largest cyprinid fish, the largemouth yellowfish Labeobarbus kimberleyensis. J Fish Biol. 2012;81:1271-1284. http://dx.doi.org/10.1111/ j.1095-8649.2012.03395.x

14. Mulder PFS. Aspects on the ecology of Barbus kimberleyensis and Barbus holubi in the Vaal River. Afr Zool. 1973;8:1-14.

15. Weyl 0 , Stadtlander T, Booth AJ. Establishment of translocated populations of smallmouth yellowfish, Labeobarbus aeneus (Pisces: Cyprinidae), in lentic and lotic habitats in the Great Fish River system, South Africa. Afr Zool. 2009;44(1):93-105. http://dx.doi.org/10.3377/004.044.0109
16. Impson D, Swartz E. Labeobarbus kimberleyensis. In: IUCN Red List of Threatened Species Version 2012.2 [database on the Internet]. c2007 [cited 2013 Jan 29]. Available from: www.iucnredlist.org

17. Swartz E, Impson D. Labeobarbus aeneus. In: IUCN Red List of Threatened Species Version 2012.2 [database on the Internet]. c2007 [cited 2013 Jan 29]. Available from: www.iucnredlist.org

18. Barlow GW. Fish behavioural ecology: Pros, cons and opportunities. In: Hunitingford FA, Torricelli P, editors. Behavioural ecology of fishes. Reading: Harwood Academic Publishers; 1993. p. 1-5.

19. Koehn JD. Why use radio tags to study freshwater fish? In: Hancock DA, Smith D, Koehn JD, editors. Fish movement and migration. Sydney: Australian Society for Fish Biology; 2000.

20. Butler SE, Wahl DH. Common carp distribution, movements, and habitat use in a river impounded by multiple low-head dams. T Am Fish Soc. 2010;139:1121-1135. http://dx.doi.org/10.1577/T09-134.1

21. Priede IG. Telemetry in assessment of environmental effects on individual fishes. In: Lucas MC, Diack I, Laird L, editors. Interactions between fisheries and the environment. Proceedings of the Institute of Fisheries Management 22nd Annual Study Course. Nottingham: Institute of Fisheries Management; 1991. p. 179-196.

22. Stormer DG, Maceina MJ. Habitat use, home range, and movement of shoal bass in Alabama. N Am J Fish Manag. 2009;29:604-613. http://dx.doi. org/10.1577/M08-123.1

23. Næsje TF, Childs AR, Cowley PD, Potts WM, Thorstad EB, Økland F. Movements of undersized spotted grunter (Pomadasys commersonnii) in the Great Fish Estuary, South Africa: Implications for fisheries management. Hydrobiologia. 2007;582:25-34. http://dx.doi.org/10.1007/s10750-006-0563-8

24. Cowley PD, Kerwath SE, Childs AR, Thorstad EB, Økland F, Næsje F. Estuarine habitat use by juvenile dusky kob Argyrosomus japonicus (Sciaenidae), with implications for management. Afr J Mar Sci. 2008;30:247-253. http://dx.doi. org/10.2989/AJMS.2008.30.2.5.555

25. O'Brien GC, Bulfin JB, Husted A, Smit NJ. A comparative behavioural assessment of an established and new tigerfish (Hydrocynus vittatus) population in two artificial impoundments in the Limpopo catchment, southern Africa. Afr J Aquat Sci. 2012;37(3):253-263. http://dx.doi.org/10 $.2989 / 16085914.2012 .723196$

26. Jepsen N, Koed A, Thorstad EB, Baras E. Surgical implantation of telemetry transmitters in fish: How much have we learned? Hydrobiologia. 2002;165:241-250.

27. Mulder PFS, Franke GW. A report on the artificial fertilization of the smallmouth yellowfish, Barbus holubi (Steindachner, 1894). J Fish Biol. 1973;5(2):143145. http://dx.doi.org/10.1111/j.1095-8649.1973.tb04442.x

28. Tómasson T, Cambray JA, Jackson PBN. Reproductive biology of four large riverine fishes (Cyprinidae) in a man-made lake, Orange River, South Africa. Hydrobiologia. 1984;112:179-195. http://dx.doi.org/10.1007/BF00008084

29. Peake S. Sodium bicarbonate and clove oil as potential anesthetics for nonsalmonid fishes. N Am J Fish Manage. 1998;18:919-924. http://dx.doi. org/10.1577/1548-8675(1998)018<0919:SBACOA>2.0.C0;2

30. Bridger CJ, Booth RK. The effects of biotelemetry transmitter presence and attachment procedures on fish physiology and behaviour. Res Fish Sci. 2003;11(1):13-34. http://dx.doi.org/10.1080/16226510390856510

31. Rogers KB, White GC. Analysis of movement and habitat use from telemetry data. In: Brown M, Guy C, editors. Analysis and interpretation of freshwater fisheries data. Bethesda, MD: American Fisheries Society; 2007. p. 625-676.

32. Hodder KH, Masters JEG, Beaumont WRC, Gozlan RE, Pinder AC, Knight $\mathrm{CM}$, et al. Techniques for evaluating the spatial behaviour of river fish. Hydrobiologia. 2007;582:257-269. http://dx.doi.org/10.1007/s10750-0060560-y

33. James CS, King JM. Ecohydraulics for South African rivers: A review and guide. WRC report no. TT 453-10. Pretoria: Water Research Commission; 2010. p. 52

34. Enders EC, Smokorowski KE, Pennell CJ, Clarke KD, Sellars B, Scruton DA. Habitat use and fish activity of landlocked Atlantic salmon and brook charr in a newly developed habitat compensation facility. Hydrobiologia. 2007;582:133-142. http://dx.doi.org/10.1007/s10750-006-0550-0 
35. Ivlev VS. Experimental ecology of the feeding in fishes. New Haven: Yale University Press; 1961.

36. Littell RC, Milliken GA, Stroup WW, Wolfinger RD. SAS system for mixed models. Cary NC: SAS Institute; 1996.

37. Burnham KP, Anderson DR. Model selection and inference: A practical information-theoretic approach. New York: Springer-Verlag; 1998.

38. Clough S, Garner P, Deans D, Ladle M. Postspawning movements and habitat selection of dace in the River Frome, Dorset, Southern England. J Fish Biol. 1998;53:1060-1070. http://dx.doi.org/10.1111/j.1095-8649.1998. tb00463.x

39. Økland F, Hay CJ, Næsje TF, Nickandor N, Thorstad EB. Learning from unsuccessful radio tagging of common carp in a Namibian reservoir. J Fish Biol. 2003;62:735-739. http://dx.doi.org/10.1046/j.1095-8649.2003.00043.x

40. Penne CR, Pierce CL. Seasonal distribution, aggregation, and habitat selection of common carp in a clear lake, lowa. T Am Fish Soc. 2008;137:1050-1062. http://dx.doi.org/10.1577/T07-112.1

41. Crook DA. Movements associated with home-range establishment by two species of lowland river fish. Canadian J Fish Aquat Sci. 2004;61:21832193. http://dx.doi.org/10.1139/f04-151

42. Stuart IG, Jones MJ. Movement of common carp, Cyprinus carpio, in a regulated Iowland Australian river: Implications for management. Fisheries Manag Ecol. 2006;13:213-219. http://dx.doi.org/10.1111/j.1365-2400.2006.00495.x

43. Dörgeloh WG. Diet and food selection of Barbus aeneus, Clarias gariepinus and Oncorhynchus mykiss in a clear man-made lake, South Africa. Water SA. 1994;20:91-98.

44. Dörgeloh WG. Food overlap between the alien Oncorhynchus mykiss and the indigenous fish species Barbus aeneus and Clarias gariepinus in a man-made lake, South Africa. Water SA. 1996;22:79-83.

45. Bruton MN. The effects of suspensoids on fish. Hydrobiologia. 1985;125:221241. http://dx.doi.org/10.1007/BF00045937

46. Eccles $\mathrm{DH}$. The effect of temperature and mass on routine oxygen consumption in the South African cyprinid fish Barbus aeneus Burchell. J Fish Biol. 1985;27:155-165.
47. Eccles DH. Development of the gut in the South African cyprinid fish Barbus aeneus (Burchell). S Afr J Zool. 1986;21:165-169. http://dx.doi. org/10.1111/j.1095-8649.1985.tb04017.x

48. Stadtlander T, Weyl OLF, Booth AJ. New distribution record for the Asian tapeworm Bothriocephalus acheilognathi Yamaguti, 1934 in the Eastern Cape Province, South Africa. Afr J Aquat Sci. 2011;36(3):339-343. http://dx.doi.or g/10.2989/16085914.2011.636914

49. Tomasson T. The biology and management considerations of abundant large cyprinids in Lake Le Roux, Orange River, South Africa [PhD thesis]. Grahamstown: Rhodes University; 1983. p. 218.

50. Laurenson LBJ, Hocutt $\mathrm{CH}$, Hecht $\mathrm{T}$. An evaluation of the success of invasive fish species of the Great Fish River. J Appl Ichthol. 1989;1:28-34. http:// dx.doi.org/10.1111/j.1439-0426.1989.tb00566.x

51. Gerber R, Smit NJ, Wagenaar GM. Age, growth rate and size at sexual maturity of Labeobarbus aeneus (Teleostei: Cyprinidae) in the middle Vaal River, South Africa. Afr J Aquat Sci. 2012;37(1):49-58. http://dx.doi.org/10.2989/16085 914.2012.666337

52. De Moor IJ, Bruton MN. Atlas of alien and translocated indigenous aquatic animals in southern Africa. A report of the Committee for Nature Conservation Research National Programme for Ecosystem Research. Report No. 144. Port Elizabeth: South African Scientific Programmes; 1998. p. 310.

53. Lenhard G, Du Plooy A. Studies on bottom deposits of the Vaal River system. Hydrobiologia. 1965;16:271-291. http://dx.doi.org/10.1007/BF00142271

54. Steyn DJ, Toerien DF. Eutrophication levels of some South African impoundments 4. Vaal Dam. Water SA. 1976;2:53-57.

55. Grobler DC, Brawer CA, Hall GC. A comparison of chemical load estimation algorithms using data obtained by sampling four South African rivers at varying frequencies. Water SA. 1982;8:121-129.

56. Grobler DC, Toerien DF, De Wet JS. Changes in turbidity as a result of mineralisation in the lower Vaal River. Water SA. 1983;9:110-116.

57. Davies BR, Day J. Vanishing waters. Cape Town: University of Cape Town Press; 1998. p. 36 